\title{
Entry of migrating American eel leptocephali into the Gulf Stream system
}

\author{
R. C. Kleckner \& J. D. McCleave \\ Migratory Fish Research Institute and Department of Zoology, University of Maine; \\ Orono, Maine 04469, USA
}

\begin{abstract}
Abundance, size and depth distributions of American eel (Anguilla rostrata) leptocephali collected in four transects across the Florida Current between the Straits of Florida and Cape Hatteras, North Carolina, were examined in order to assess the relative importance of two migration routes into the Gulf Stream system. A nine-fold increase in the abundance and an increase in the mean length of leptocephali collected in the Florida Current north of the Straits of Florida indicate that most leptocephali enter the Gulf Stream system directly from the Sargasso Sea rather than by a more southern route through the Bahama Islands. Leptocephali were concentrated in the upper $140 \mathrm{~m}$ at night and upper $350 \mathrm{~m}$ during the day. Wide vertical ranges in daytime collections precluded more refined estimation of vertical distribution. The collection of eight small leptocephali (11 to $17 \mathrm{~mm}$ total length) in the western Caribbean Sea is discussed in relation to the origin of leptocephali taken in the Straits of Florida.
\end{abstract}

\section{INTRODUCTION}

Information on the migration routes followed by American eel, Anguilla rostrata, leptocephali between their natal area east of the Bahama Islands and the coast of North America is fragmentary and incomplete. Surface currents are no doubt responsible for the initial movement of the smallest larvae from the spawning area (Schmidt, 1922, 1925). Harden Jones (1968) speculated that surface currents in this region would carry American eel leptocephali north of the Bahama Island chain and into the Gulf Stream system east of Cape Hatteras, North Carolina. American eel leptocephali are common in summer collections along the main axis of the Gulf Stream system both north and south of Cape Hatteras (Vladykov \& March, 1975). Leptocephali are also present in the Florida Current east of Miami, Florida, between May and August (Smith, 1968). It is not known whether these leptocephali enter the Florida Current from the east via the Old Bahama, Nicholas and Santaren Channels or from the Caribbean Sea via the Yucatan Strait and Gulf Loop Current.

The studies cited above suggest a dual input of American eel leptocephali into the Gulf Stream system, one via the Florida Current and the other from the Sargasso Sea north of Grand Bahama Island. In order to assess the relative importance of the two migration routes, we have examined (1) the abundance, size and depth distributions of leptocephali collected along four transects crossing the main axis of the Florida Current between West Palm Beach, Florida, and Cape Hatteras, North Carolina, and (2) the 
specimen and collection data for a group of small American eel leptocephali from the Yucatan Strait in the western Caribbean Sea, a potential source of leptocephali for the Florida Current.

\section{MATERIALS AND METHODS}

The Florida Current samples were borrowed from the Woods Hole Oceanographic Institution collections held by the Department of Fishes, Museum of Comparative Zoology, Harvard University, Cambridge, Massachusetts. They were collected between 29 July and 16 August 1978, on R. V. Oceanus cruise 49 by R. H. Backus and J. D. Craddock. Four trawl station transects were made perpendicular to the historical main

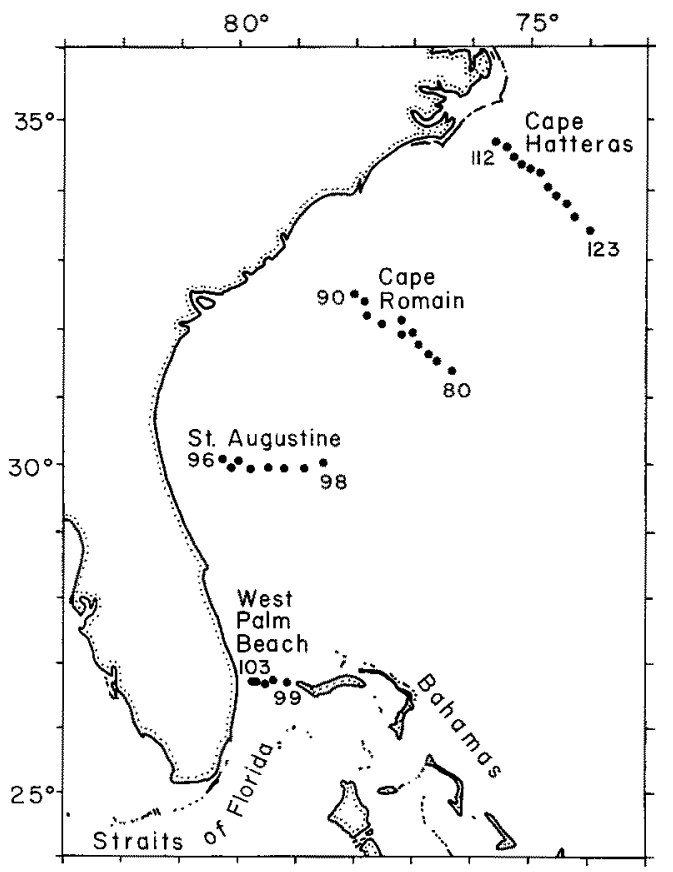

Fig. 1. North Atlantic Ocean from Cape Hatteras to the Straits of Florida showing Florida Current transect and sample locations including station numbers

axis of the Florida Current between West Palm Beach, Florida, and Cape Hatteras, North Carolina (Fig. 1). The transects extend seaward from slope water, across the Florida Current and into water of Sargasso Sea origin.

All collections were taken with a $10 \mathrm{~m}$ Multiple Opening Closing Net and Environmental Sensing System (MOCNESS-10). This system fished a series of nets sequentially during each oblique trawl. The mouth area of the MOCNESS-10 was $10 \mathrm{~m}^{2}$ when the frame of the net was tilted to $45^{\circ}$ during fishing. The netting was $3.5 \mathrm{~mm}$ circular mesh throughout. Sensors on the MOCNESS-10 measured pressure (depth), speed through the water, frame angle and net opening and closing. This information was transmitted via 
the towing cable to shipboard displays and recorders. Estimates of the volume of water filtered by each net were calculated from this data.

Identification of American and European eel leptocephali ( $A$, rostrata and $A$. anguilla) followed Smith (1979). Total length was measured from the anterior tip of the teeth to the tip of the caudal fin rays. Total length is approximately 2 to $3 \%$ longer than standard length, which is measured from the tip of the snout to the caudal fin base (F.-W. Tesch, personal communication). Specimens were fixed and preserved in $10 \%$ formalin.

Crude estimates of the relative abundance of American eel leptocephali at each trawl station were calculated as follows: (1) only nets with all or part of their sampling effort in the upper $140 \mathrm{~m}$ are included in the estimates (see "Results" for vertical distribution range), (2) estimates of the water volume filtered for nets including a sampling component below $140 \mathrm{~m}$ were proportionally reduced to include only the percentage filtered within $140 \mathrm{~m}$ of the surface, and (3) the total number of leptocephali collected by all trawls at a station were divided by the total estimated water volume filtered in the upper $140 \mathrm{~m}$ by all nets fished at the station.

Temperature-depth data from expendable bathythermograph casts and characterizations of the associated mesopelagic fish fauna provided by J. D. Craddock were utilized to define the water mass sampled at each station. The Sargasso Sea fauna was characterized by the presence of Pollichthys mauli (Gonostomatidae) and Lepidophanes gaussi (Myctophidae), the Gulf Stream system fauna by tropical species, such as Lepidophanes guentheri, Diaphus dumerillii, and D. luetkeni (Myctophidae), and the slope water fauna by temperate species, such as Ceratoscopelus maderensis and Benthosema glaciale (Backus et al., 1970, 1977).

For analyses of length and relative abundance, samples of leptocephali were grouped within transects by their associated types of mesopelagic fish fauna. Those samples whose fauna included slope water fauna or Sargasso Sea fauna as well as Gulf Stream fauna were grouped with samples whose fauna was a pure Gulf Stream one. A two-way analysis of variance of mean length by transect and faunal assemblage type was conducted using the general linear model for unbalanced data. Because the interaction between transect and faunal type was significant $(\mathrm{P}<0.001)$, the following one-way analyses of variance were done: length by transect for Gulf Stream faunal type only, length by transect for Sargasso Sea faunal type only, and length by water type for each of the three northern transects. Duncan's test was applied if there were more than two levels of the independent variable. Significance criterion was $P<0.05$. Similar analyses were not performed on the relative abundances, because the estimates of abundance are crude.

Specimen and collection data for the Caribbean Sea samples were provided by D. G. Smith of the University of Texas Marine Biomedical Institute, Galveston, Texas. These samples were collected with a two-meter ring net of $570 \mu \mathrm{m}$ Nitex mesh at $20^{\circ} 30^{\prime} \mathrm{N}, 87^{\circ}$ $00^{\prime} \mathrm{W}$ between the Yucatan Peninsula and Isla Cozumel.

\section{RESULTS}

American eel leptocephali were concentrated in the upper $140 \mathrm{~m}$ at night in the transect collections. Ninety-six percent of all specimens taken in nets sampling discrete depth ranges at night were collected in this layer (Table 1). Unfortunately, the narrowest 
Table 1. Vertical distribution of American eel leptocephali in MOCNESS-10 collections in the Florida Current

\begin{tabular}{|ccrcc|}
\hline \multirow{2}{*}{ Day } & $\begin{array}{c}\text { Depth range } \\
(\mathrm{m})\end{array}$ & $\begin{array}{c}\text { Number of } \\
\text { American eel } \\
\text { leptocephali }\end{array}$ & $\begin{array}{c}\text { Volume of water } \\
\text { filtered } \\
\left(10^{4} \mathrm{~m}^{3}\right)\end{array}$ & $\begin{array}{c}\text { Catch rate } \\
\left(\mathrm{No} . / 10^{4} \mathrm{~m}^{3}\right)\end{array}$ \\
& $0-350$ & $65(91.5 \%)$ & 36.8 & 1.77 \\
& $340-750$ & $5(7.0 \%)$ & 89.6 & 0.06 \\
Night & 1 & $(1.4 \%)$ & 52.4 & 0.02 \\
& $670-1200$ & $340(95.8 \%)$ & 67.5 & 5.04 \\
& $0-140$ & $12(3.3 \%)$ & 18.8 & 0.64 \\
& $90-400$ & $2(0.6 \%)$ & 67.9 & 0.03 \\
\hline
\end{tabular}

depth range fished in the surface waters during the day was 0 to $350 \mathrm{~m}$. Nets fished obliquely between 0 and $350 \mathrm{~m}$ collected $92 \%$ of the specimens taken in daytime collections (Table 1). Clearly, American eel leptocephali in these collections did not migrate diumally to depths below $350 \mathrm{~m}$. The question of diel vertical migration within the upper $350 \mathrm{~m}$ is not resolved by these data.

The mean total length of American eel leptocephali in collections associated with Gulf Stream mesopelagic fish fauna increased from south to north (Fig. 2). Cape Hatteras leptocephali (samples 115-118) were significantly longer than Cape Romain leptocephali (samples 85-87) which were in turn significantly longer than St. Augustine and West Palm Beach leptocephali (samples 91-94 and 99-106, respectively). Similarly the mean length of leptocephali associated with Sargasso Sea fauna was significantly greater at Cape Hatteras (samples 119-123) than at Cape Romain and St. Augustine (samples 80-83 and 97-98, respectively).

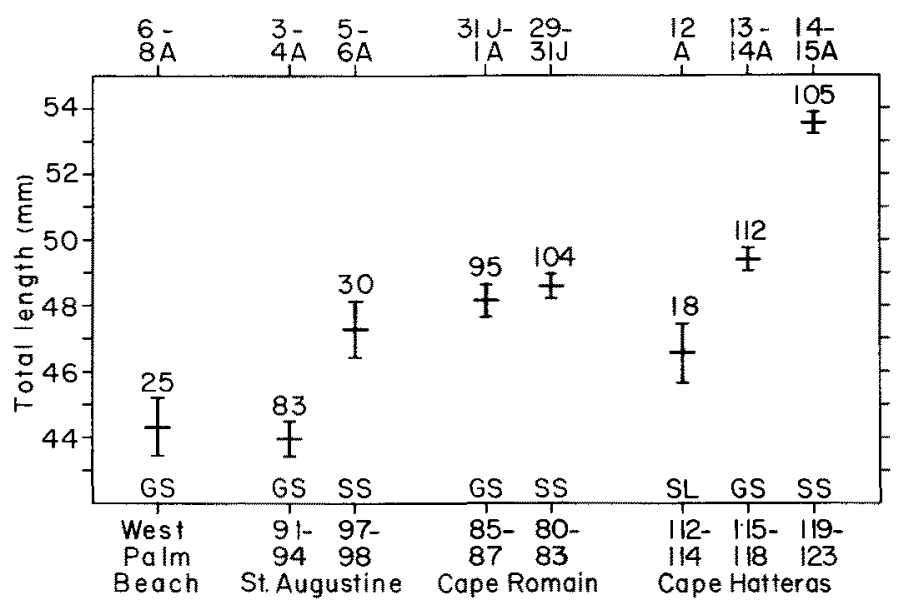

Fig. 2. Mean total lengths, standard errors and sample sizes of American eel leptocephali in Florida Current transect samples. Samples within transects are grouped on the basis of their associated mesopelagic ichthyofauna (SL = slope water fauna, GS = Gulf Stream system fauna, SS = Sargasso Sea fauna). The upper caption lists the day and month $(\mathrm{J}=\mathrm{July}, \mathrm{A}=\mathrm{August})$ 
This south to north increase in length is apparently due to the input of larger specimens from the western Sargasso Sea. Leptocephali taken at the eastern ends of the St. Augustine and Cape Hatteras transects, in collections with a Sargasso Sea faunal composition (samples 97-98 and 119-123), were significantly longer than those collected to the west on their respective transects. Leptocephali taken at Cape Romain were not significantly different in mean length from west (samples 85-87) to east (samples 80-83).

Leptocephali associated with slope water fauna were taken only at Cape Hatteras; their mean length was only slightly greater than that of leptocephali taken much farther south at St. Augustine and West Palm Beach.

The observed length distributions among and along transects apparently reflect real geographic differences, rather than temporal ones, at least in the Florida Current itself. The mean length of leptocephali collected at the western end of the Cape Romain transect on July 31 and August 1 (samples 85-87, $48.1 \pm 0.48 \mathrm{~mm}$, mean \pm standard error) was not significantly different from that of leptocephali collected there 9-10 days later (sample 110, $49.1 \pm 0.68 \mathrm{~mm}$ ) (t test, $\mathrm{P}>0.10$ ). Similarly the mean length of leptocephali collected at Cape Hatteras on August 13 (sample 115, $46.6 \pm 1.24 \mathrm{~mm}$ ) was not significantly different at the same location 3 days later (sample 124, $46.9 \pm 0.87 \mathrm{~mm}$ ) $(\mathrm{P}>0.10)$.

The mean catch of American eel leptocephali per unit effort in those collections characterized by a Gulf Stream system fish fauna increased dramatically northward from

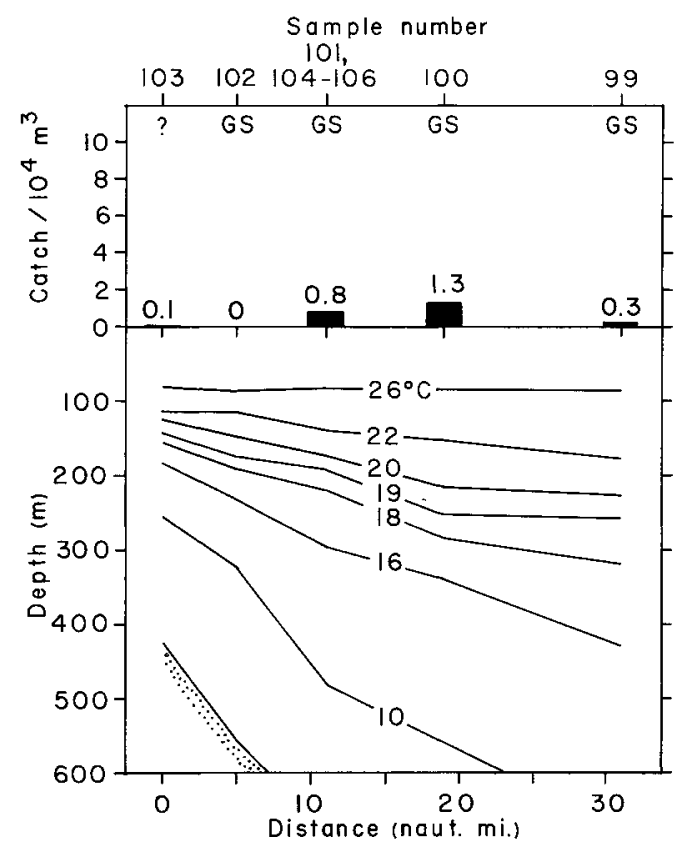

Fig. 3. West Palm Beach transect. Bar graph shows catches of American eel leptocephali per $10^{4} \mathrm{~m}^{3}$ of water filtered. Sample numbers and characterizations of their associated mesopelagic ichthyofauna are listed at the top of the figure (? = no mesopelagic fauna caught, GS = Gulf Stream system fauna). The depth to selected isotherms at each sample location is shown in the bottom half of the figure. The horizontal scale is the distance from west to east along the length of the transect 


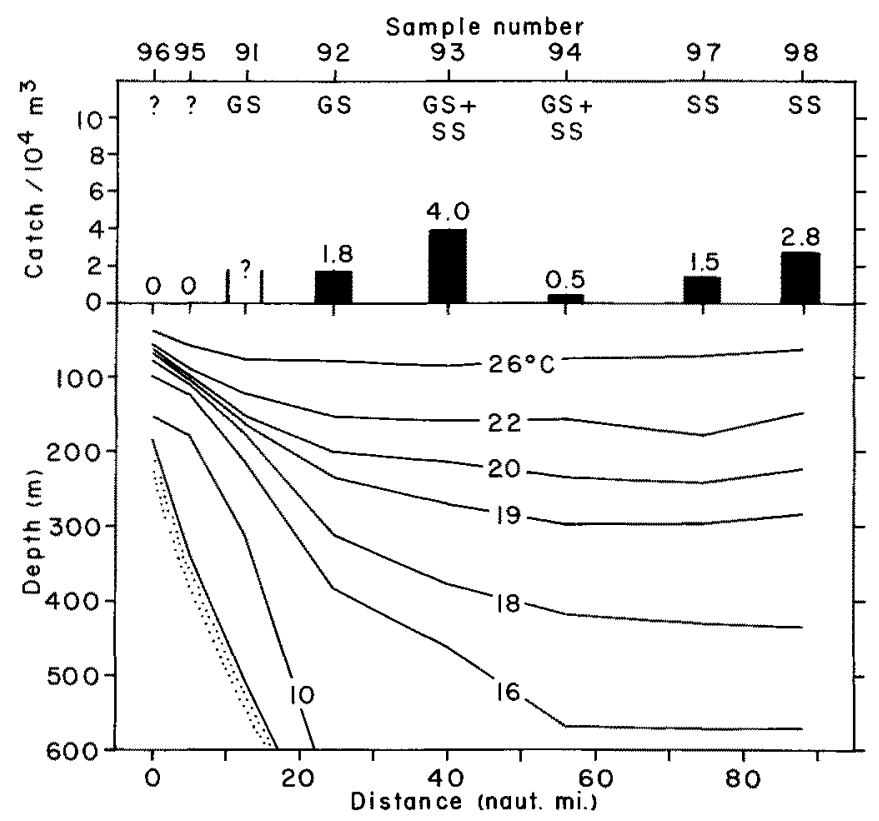

Fig. 4. St. Augustine transect. Bar graph shows catches of American eel leptocephali per $10^{4} \mathrm{~m}^{3}$ of water filtered. Sample numbers and characterizations of their associated mesopelagic ichthyofauna are listed at the top of the figure (? = no mesopelagic fauna caught, GS = Gulf Stream fauna, SS = Sargasso Sea fauna). Catch rate was not calculated for leptocephali collected in sample 91 due to gear failure. The depth to selected isotherms at each sample location is shown in the bottom half of the figure. The horizontal scale is the distance from west to east along the length of the transect

the Straits of Florida. Compared with their abundance in the West Palm Beach collections (Fig. 3: samples 99-106) leptocephali were approximately three times more abundant at St. Augustine (Fig. 4: samples 92-94), six times more abundant at Cape Romain (Fig. 5: samples 85-88) and nine times more abundant at Cape Hatteras (Fig. 6: samples 115-118).

At Cape Romain American eel. leptocephali were approximately three times more abundant in collections associated with a Sargasso Sea mesopelagic fish fauna (Fig. 5: samples 80-83) than they were to the west in collections with a Gulf Stream system fauna (samples 85-88). Sample 84, which also had a high leptocephalus catch rate, did not include mesopelagic species. The eastern Cape Romain samples, including sample 84 , were all associated with a pronounced thickening of the " $18^{\circ} \mathrm{C}$ water" typical of the northern Sargasso Sea (Pickard, 1979). Such high leptocephalus catch rates were repeated only in Cape Hatteras transect sample 122 (Fig. 6). Other samples characterized by a Sargasso Sea fauna at Cape Hatteras and at St. Augustine (Fig. 4) took leptocephali at catch rates approximately equal to their respective samples with a Gulf Stream system fauna.

American eel leptocephali were not taken in slope water collections at St. Augustine (Fig. 4: samples 95 and 96) or Cape Romain (Fig. 5: samples 89 and 90). At Cape Hatteras 


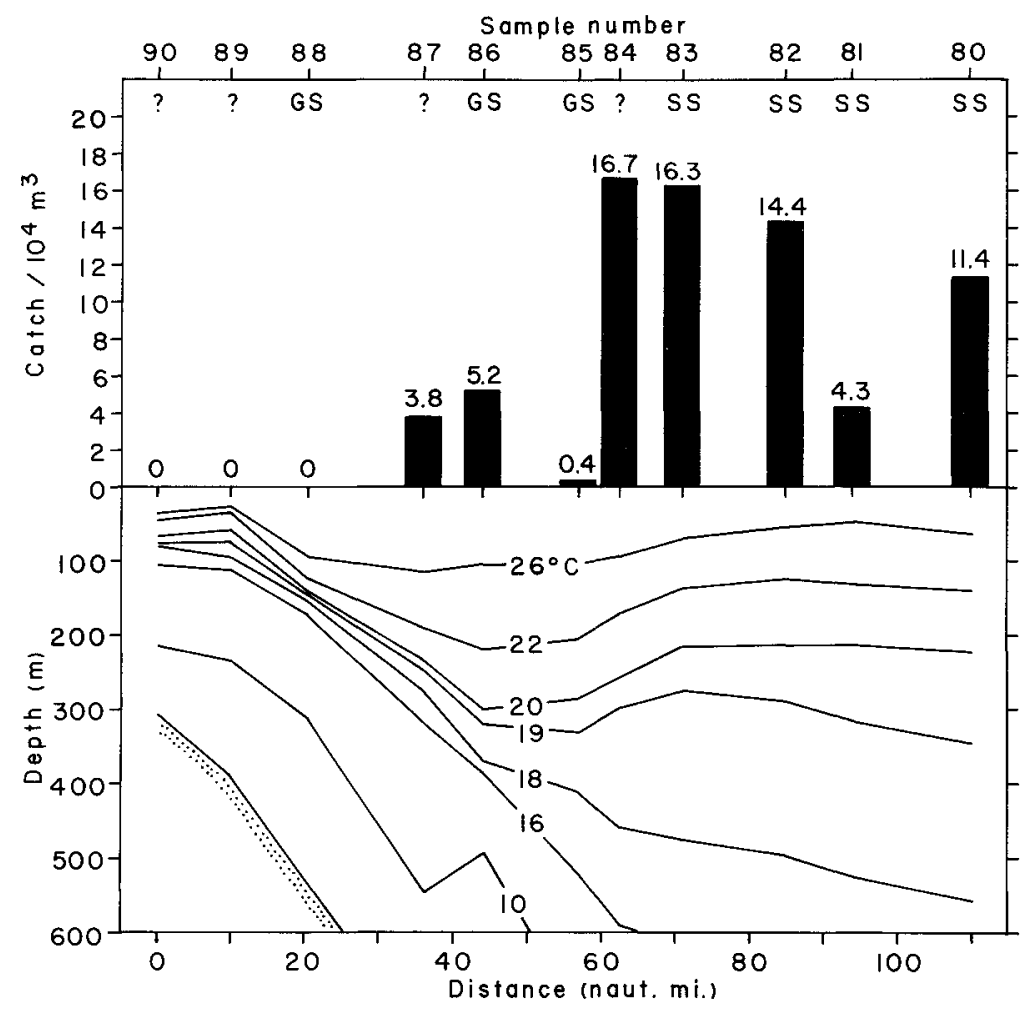

Fig. 5. Cape Romain transect. Bar graph shows catches of American eel leptocephali per $10^{4} \mathrm{~m}^{3}$ of water filtered. Sample numbers and characterizations of their associated mesopelagic ichthyofauna are listed at the top of the figure $(?=$ no mesopelagic fauna caught, GS $=$ Gulf Stream system fauna, SS = Sargasso Sea fauna). The depth to selected isotherms is shown in the bottom half of the

figure. The horizontal scale is the distance from west to east along the length of the transect

they were taken in low numbers in slope water collections at the western end of the transect (Fig. 6: samples 112 and 113). Sample 114, also characterized by a slope water faunal composition, had a substantially higher catch (Fig. 6). The compressed downward sloping isotherms east of station 114 delineate the western edge of the Florida Current.

The relative abundance of American eel leptocephali at these geographic locations in the Florida Current, did not change dramatically over short times. Four samples taken during a $39 \mathrm{~h}$ period at West Palm Beach (Fig. 3: samples 101 and 104-106) took from 0.5 to 2.6 leptocephali per $10^{4} \mathrm{~m}^{3}$ of water filtered. At Cape Romain station 86 , collections taken three days after the initial sample (Fig. 5) took 1.7 leptocephali per $10^{4} \mathrm{~m}^{3}$ and at Cape Hatteras station 115, collections taken nine days after the initial sample (Fig. 6) took 3.5 leptocephali per $10^{4} \mathrm{~m}^{3}$.

A total of 58 European eel leptocephali were taken in the Florida Current transect collections. They were distributed as follows: (1) West Palm Beach transect $=1$ specimen, (2) St. Augustine transect $=0$ specimens, (3) Cape Romain transect, Gulf Stream fauna stations 85 to $88=8$ specimens and Sargasso Sea fauna stations 80 to $83=16$ 


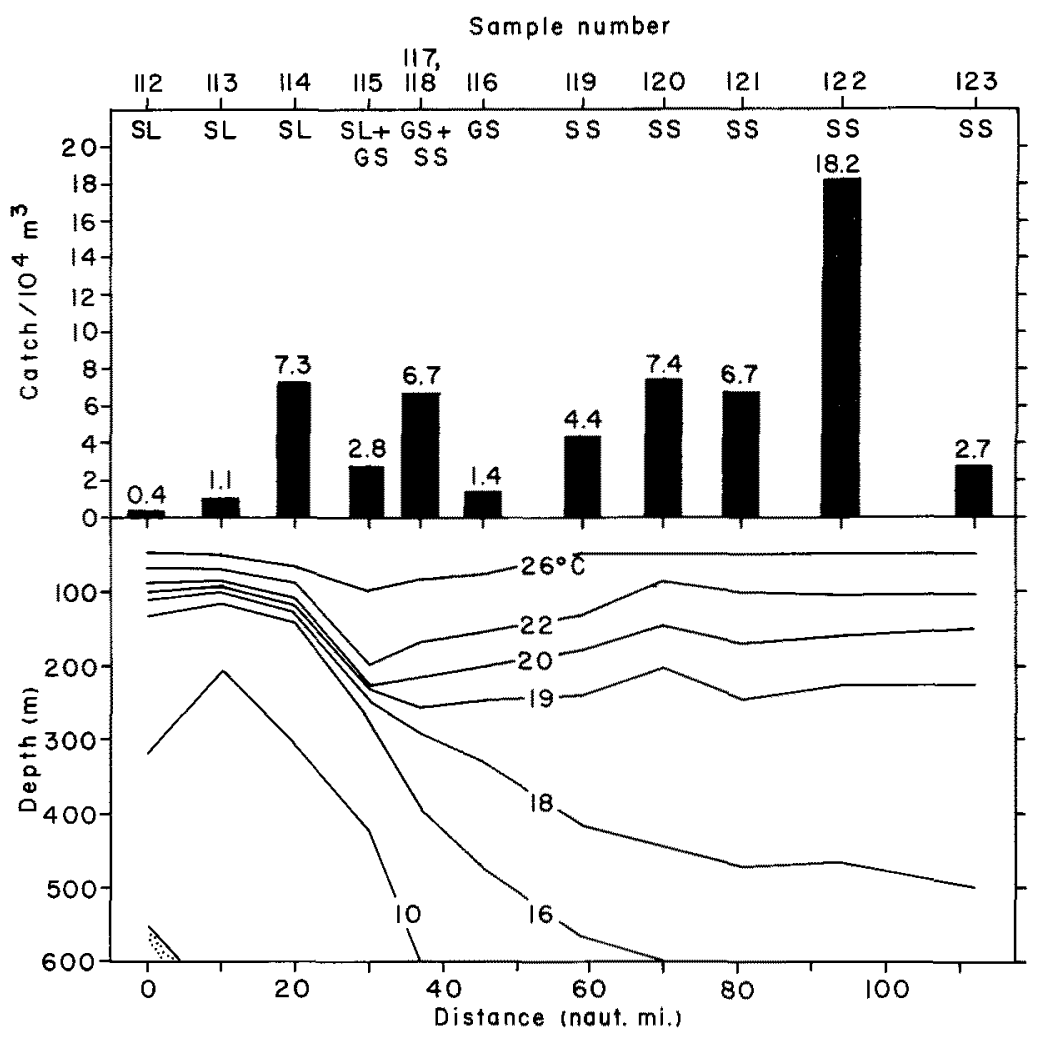

Fig. 6. Cape Hatteras transect. Bar graph shows catches of American eel leptocephali per $10^{4} \mathrm{~m}^{3}$ of water filtered. Sample numbers and characterizations of their associated mesopelagic ichthyofauna are listed at the top of the figure (SL = Slope water fauna, GS = Gulf Stream system fauna, SS = Sargasso Sea fauna). The depth to selected isotherms is shown in the bottom half of the figure.

The horizontal scale is the distance from west to east along the length of the transect

specimens, and (4) Cape Hatteras transect, Gulf Stream fauna stations 115 to $118=16$ specimens and Sargasso Sea fauna stations 119 to $123=17$ specimens. 0-group leptocephali averaged $38.4 \mathrm{~mm}$ in length $(\mathrm{SE}=0.319, \mathrm{n}=48$ ) and 1-group leptocephali averaged $50.1 \mathrm{~mm}$ in length ( $\mathrm{SE}=0.795, \mathrm{n}=10$ ). Catch rates of European eel leptocephali in these collections were too low to permit a detailed analysis of distribution.

Eight American eel leptocephali, 11 to $17 \mathrm{~mm}$ total length, were collected during mid-April over the continental shelf of the Yucatan Peninsula about $110 \mathrm{~km}$ south of the Yucatan Channel. Two leptocephali 45 and $48 \mathrm{~mm}$ total length were collected at this location in November.

\section{DISCUSSION}

The ninefold increase in the abundance of American eel leptocephali in the Florida Current between the northern Straits of Florida and Cape Hatteras clearly indicates that most American eels enter the Gulf Stream system directly from the Sargasso Sea rather 
than by a more southern route. This interpretation is supported by the increase in mean length of American eel leptocephali in Florida Current collections taken north of the Straits of Florida and by the increase in specimen length from west to east along the St. Augustine and Cape Hatteras transects.

The largest input of American eel leptocephali into the Gulf Stream system south of Cape Hatteras occurs north of $30^{\circ} \mathrm{N}$. This coincides with a predicted increase in the volume transport of the Florida Current between Jacksonville, Florida, and Cape Hatteras (Knauss, 1969; Richardson et al., 1969; Richardson \& Knauss, 1971; Worthington, 1976; Stommel et al., 1978). The abundances and depth distributions of leptocephali support the idea that some of the increase in volume transport must be due to input of surface waters from the western Sargasso Sea.

These leptocephali probably drift passively to the eastern edge of the Florida Current from a spawning area east of the Bahama Islands. The presence of a strong, broad and persistent Antilles Current flowing northwest outside the Bahama Islands (Wüst, 1924) has been challenged on the basis of geostrophic flow calculations (Ingham, 1975). Rather, a variable sluggish flow to the north is predicted (Ingham, 1975; Gunn \& Ingham, 1977). The latter is more consistent with the transport of developing leptocephali to the edge of the Florida Current during the six month interval between the predicted spawning peak in February (Kleckner \& McCleave, 1980) and the dates of collection of the samples used in our study.

The distribution of abundance concentrations and size groups of American eel leptocephali in these samples is intriguing when considered relative to average summer flow patterns of surface currents in the western Sargasso Sea (Naval Oceanographic Office, 1978). The eastern half of the Cape Romain transect was in an area of bizonal flow with observations of surface currents directed to the northeast and southwest nearly equal in frequency. South and southwest of this area the prevailing flow is to the southwest, while to the north and northeast a prevailing northeasterly flow parallels the main axis of the Florida Current to the west. East and southeast of the Cape Romain transect the surface currents are variable. The elevated concentration of leptocephali at the eastern end of the Cape Romain transect thus lies in an area of opposing current patterns from which dispersal could take place to the southwest or northeast. The similarity in mean length between these leptocephali and those taken at the eastern end of the St. Augustine transect, at the western end of the Cape Romain transect and at the center of the Cape Hatteras transect suggests that these groups may be drawn from the same source.

The absence of significant variation in mean length across the Cape Romain transect may be due to a persistent and pronounced seaward deflection in the western margin of the Florida Current caused by the Charleston Bump (Brooks \& Bane, 1978; Legeckis, 1979). The Charleston Bump, located $100 \mathrm{~km}$ upstream from the Cape Romain transect, is also apparently responsible for cylic waves and eddies downstream (Legeckis, 1979). This may have caused lateral mixing across the Florida Current; however, such mixing is not indicated by faunal characterizations (Fig. 5).

The significantly longer American eel leptocephali collected along the eastern half of the Cape Hatteras transect must be from a source with a different history. Cold-core eddies frequently pass south through the area east of the Florida Current at Cape Hatteras (Richardson, 1980). However, the temperature-depth plot for this transect does 
not have the elevated isotherms associated with a cold-core eddy (Fig. 6). In the absence of sampling further to the south and east we have no explanation of the origin of this group.

Factors responsible for the range of $9 \mathrm{~mm}$ in mean length found among collections of American eel leptocephali in the Florida Current and western Sargasso Sea are unknown. Possibly the smaller leptocephali that entered the Florida Current through the Straits of Florida or through the Bahamas were the progeny of later spawning. Alternatively these smaller larvae may have hatched and drifted in regions whose environmental characteristics caused slower growth.

The eight 11 to $17 \mathrm{~mm}$ American eel leptocephali collected southwest of the Yucatan Channel are the smallest specimens ever reported from the Caribbean Sea. Specimens longer than $30 \mathrm{~mm}$ have previously been reported (Schmidt, 1925; Vadykov \& March, 1975). The presence of such small leptocephali in the Caribbean Sea raises the possibility that American eels may occasionally reproduce outside of the southwestern Sargasso Sea. Representations of Caribbean Sea surface currents derived from long term averages of ship-drift observations (Wüst, 1964) and average geostrophic circulation calculations (Gordon, 1967) may be used to suggest that leptocephali collected along the east coast of the Yucatan Peninsula could have been transported by the Caribbean Current from a spawning area in the central or eastern Caribbean Sea or in the North Atlantic to the east of the Lesser Antilles. Data from the trajectories of satellite-tracked drifting buoys (Molinari et al., 1981) and recoveries of drifting tags (Brucks, 1971; Murphy et al., 1975; Duncan et al., 1977) support this interpretation. However, the recovery along the eastern Yucatan Peninsula of drifting tags released in the Mona Passage (Metcalf et al., 1977) and near the Windward and Jamaica Passages (Murphy et al., 1975; Grant \& Wyatt, 1980) opens the possibility that these leptocephali may have originated at spawing areas north of Hispaniola.

Irrespective of their natal area, American eel leptocephali in the Caribbean Sea could be carried to the Straits of Florida by the Caribbean and Gulf Loop Currents (Murphy et al., 1975; Maul, 1977). Leptocephali collected at West Palm Beach may have entered the Florida Current by this route or by drifting west from the Sargasso Sea through the Bahama Island chain to the Straits of Florida. Drift bottle studies by Day (unpublished manuscript, 1954) established the feasibility of the latter. The relative importance of these routes may not be ascertained from our data.

Acknowledgements. We thank Dr. J. E. Craddock for temperature-depth data and characterizations of the associated mesopelagic fish fauna, Ms. B. D. Gustafson for laboratory assistance and Dr. J. H. Power for comments and suggestions on the manuscript. This study was supported by the National Science Foundation, grant number OCE-7719440, and by the National Geographic Society.

\section{LITERATURE CITED}

Backus, R. H., Craddock, J. E., Haedrich, R. L. \& Shores, D. L., 1970. The distribution of mesopelagic fishes in the equatorial and western North Atlantic Ocean. - J. mar. Res, 28, 179-201.

Backus, R. H., Craddock, J. E., Haedrich, R. L. \& Robison, B. H, 1977. Atlantic mesopelagic zoogeography, In: Fishes of the western North Atlantic. Ed. by R. H. Gibbs. Yale Univ, New Haven, 7, 266-287. (Mem. Sears Fdn mar, Res. 1.)

Brooks, D. A. \& Bane, J. M., 1978. Gulf Stream deflection by a bottom feature off Charleston, South Carolina. - Science, N. Y. 201, 1225-1226. 
Brucks, J. T., 1971. Currents of the Caribbean and adjacent regions as deduced from drift bottle studies. - Bull. mar. Sci. 21, 455-465.

Day, C. G., 1954. A note on the circulation in the region northeast of the Bahama Islands. - Tech. Rep. Woods Hole oceanogr. Inst. 54-4, 1-6.

Duncan, C. P., Atwood, D. K., Duncan, J. R. \& Froelich, P. N., 1977. Drift bottle returns from the Caribbean. - Bull. mar. Sci. 27, 581-586.

Gordon, A. L., 1967. Circulation of the Caribbean Sea. - J. geophys. Res. 72, 6207-6223.

Grant, C. J. \& Wyatt, J. R., 1980. Surface currents in the eastern Cayman and western Caribbean Seas. - Bull. mar. Sci. 30, 613-622.

Gunn, J. T. \& Ingham, M. C., 1977. A note on: "Velocity and transport of the Antilles Current northeast of the Bahama Islands." - Fish. Bull. U. S. 75, 222-225.

Harden Jones, F. R., 1968. Fish migration. Arnold, London, 325 pp.

Ingham, M. C., 1975. Velocity and transport of the Antilles Current northeast of the Bahama Islands. - Fish. Bull. U. S. 73, 626-632.

Kleckner, R. C. \& McCleave, J. D., 1980. Spatial and temporal distribution of Anguilla rostrata and Anguilla anguilla leptocephali found in North American ichthyoplankton collections. - C.M. ICES $M 21,1-18$.

Knauss, J. A., 1969. A note on the transport of the Gulf Stream. -Deep-Sea Res. (Suppl.) 16, 117-123.

Legeckis, R. V., 1979. Satellite observations of the influence of bottom topography on the seaward deflection of the Gulf Stream off Charleston, South Carolina. - J. phys. Oceanogr. 9, 483-497.

Maul, G. A., 1977. The annual cycle of the Gulf Loop Current Part I: Observations during a one year time series. - J. mar. Res. 35, 29-47.

Metcalf, W. G., Stalcup, M. C. \& Atwood, D. K., 1977. Mona Passage drift bottle study. - Bull. mar. Sci, 27, 586-591.

Molinari, R. L., Spillane, M., Brooks, I., Atwood, D. \& Duckett, C., 1981. Surface currents in the Caribbean Sea as deduced from lagrangian observations. - J. geophys. Res. 86, 6537-6542.

Murphy, D. L., Paskausky, D. F., Nowlin, W. D. \& Merrell, W. J., 1975. Movement of surface drifters in the American Mediterranean. - J. phys. Oceanogr. 5, 549-551.

Naval Oceanographic Office, 1978. Surface currents. West central North Atlantic Ocean including east coast of the United States. - Spec. Publ. U. S. Naval oceanogr. Office 1400-NA 6, 1-14.

Pickard, G. L., 1979. Descriptive physical oceanography. Pergamon Press, Oxford. 233 pp.

Richardson, P. L., 1980. Gulf Stream ring trajectories. - J. phys. Oceanogr. 10, 90-104.

Richardson, P. L. \& Knauss, J. A., 1971. Gulf Stream and western boundary undercurrent observations at Cape Hatteras. - Deep-Sea Res. 18, 1089-1109.

Richardson, W. S., Schmitz, W. J. \& Niiler, P. P., 1969. The velocity structure of the Florida Current from the Florida Straits to Cape Fear. - Deep-Sea Res. (Suppl.) 16, 225-231.

Schmidt, J., 1922. The breeding places of the eel. - Phil. Trans. R. Soc. (B) 211, 179-208.

Schmidt, J., 1925. The breeding places of the eel. - Rep. Smithson. Instn 1924, 279-316.

Smith, D. G., 1968. The occurrence of larvae of the American eel, Anguilla rostrata, in the Straits of Florida and nearby areas. - Bull. mar. Sci. 18, 280-293.

Smith, D. G., 1979. Guide to the leptocephali (Elopiformes, Anguilliformes, and Notacanthiformes). - NOAA Tech. Rep. NMFS Circ. 424, 1-39.

Stommel, H., Niiler, P. \& Anati, D., 1978. Dynamic topography and recirculation of the North Atlantic. - J. mar. Res. 36, 449-468.

Vladykov, V. D. \& March, H., 1975. Distribution of leptocephali of the two species of Anguilla in the western North Atlantic, based on collections made between 1933 and 1968. - Syllogeus 6, 1-38.

Worthington, L. V., 1976. On the North Atlantic circulation. Johns Hopkins Univ., Baltimore, 110 pp.

Wüst, G., 1924. Florida- und Antillenstrom. Eine hydrodynamische Untersuchung. - Veröff. Inst. Meeresk. Univ. Berlin 12, 1-48.

Wüst, G., 1964. Stratification and circulation in the Antillean - Caribbean basins. Columbia University Press, New York, 201 pp. 